Cite this: New J. Chem., 2015, 39, 4086

\title{
Synthesis and dye sensitized solar cell applications of Bodipy derivatives with bis-dimethylfluorenyl amine donor groups $\dagger$
}

\author{
Yusuf Çakmak, *a Safacan Kolemen, ${ }^{a}$ Muhammed Buyuktemiz, ${ }^{\text {b }}$ Yavuz Dede ${ }^{\mathrm{b}}$ and \\ Sule Erten-Ela*c
}

Received (in Victoria, Australia)

24th December 2014,

Accepted 12th March 2015

DOI: 10.1039/c4nj02393e

www.rsc.org/njc

\begin{abstract}
Three Bodipy dyes with strong absorptivities in the visible and near infrared regions were designed, synthesized and their potential as photosensitizers for liquid electrolyte-based dye sensitized solar cells have been evaluated. For the first time Bodipy derivatives with bis-dimethylfluorenyl amine donor groups which were known for their bulky structures as donor groups have been used together. We altered our mostly used triphenylamine group with these and investigated the dye-sensitized solar cell efficiencies of this new class of Bodipy dyes.
\end{abstract}

\section{Introduction}

The dye-sensitized solar cell (DSSC) concept is thought of as an important alternative to the traditional semiconductor based solar cells because of the limits and problems of these widely used constructs. ${ }^{1}$ An important part of this emerging field is the choice of sensitizer. ${ }^{2}$ Bodipy dyes which we use in our studies have a strong reputation as fluorophores ${ }^{3}$ and in recent years a number of DSSCs have been studied using these compounds. The first rationally designed example of a Bodipybased sensitizer was reported a few years ago, ${ }^{4}$ followed by a few more recent articles including both liquid electrolyte and solid state based DSSCs. ${ }^{5}$ A few years ago, we have achieved an overall efficiency of 2.46 using a long wavelength-absorbing derivative. ${ }^{6}$ Lately, more efficient liquid electrolyte-based DSSCs based on Bodipy structures have been achieved with record values of overall power-to-current conversion efficiency of $4.89 \%$ and $5.31 \%$ by Zhang's group ${ }^{8}$ and $6.06 \%$ by Kubo's group. ${ }^{9}$ It is clear that the optimal solar cell performance of a photosensitizer is dependent on a large number of parameters; however, the absorption range, anchoring groups and the direction of electronic reorganization upon excitation should be among the most important ones. ${ }^{7}$ Recent developments in Bodipy chemistry allow diverse modifications on the core structure. ${ }^{3,8}$ Through these modifications, many

\footnotetext{
${ }^{a}$ National Nanotechnology Research Center (UNAM), Bilkent University, Bilkent Ankara, 06800, Turkey

${ }^{b}$ Department of Chemistry, Faculty of Science, Gazi University, Teknikokullar, Ankara 06500, Turkey

${ }^{c}$ Institute of Solar Energy, Ege University, Izmir, 35100, Turkey.

E-mail: suleerten@yahoo.com; Tel: +90 2323111231

$\dagger$ Electronic supplementary information (ESI) available. See DOI: 10.1039/ c4nj02393e
}

characteristics of the parent chromophore can be altered in the desired direction, for example, it is possible to shift the absorption wavelength through the red end of the electromagnetic spectrum by just simple chemical transformations. ${ }^{8 b, 9}$ In addition to these, solubility and aggregation characteristics of these dyes can also be modulated as needed. ${ }^{3}$

Thiophene is known to be used frequently in DSSCs because of its electron transfer ability. ${ }^{10}$ Since electron delocalization through the $\pi$-system is an important factor in DSSCs, we have appended the thiophene unit to the Bodipy structure. The thiophene carboxylic acid unit has been attached to the meso (8-) position of the Bodipy core, since this position was calculated be more feasible for electron injection. ${ }^{5 a, 6}$ Direct attachment of the thiophene unit to the core was also thought to enhance the efficiency of electron transfer. As an anchoring group, the carboxylic acid was used due to the synthetic problems we faced while trying to attach the cyanoacetic acid moiety, which is also known to bind efficiently to the $\mathrm{TiO}_{2}$ surface and increases the electron withdrawing ability of the electron-injecting unit. The electron donor part is also an important parameter in DSSC design and efficient usage of the donor groups has a substantial role in increased cell efficiencies. In this study, we altered our mostly used triphenylamine group with the bis-dimethylfluorenyl amine group. This group has been successfully utilized in some literature reports $^{11}$ and due to its bulky structure it has been widely proposed as a donor group. It has also been suggested that using bulky structures increases the stability of oxidized dye molecules. Hence, in Bodipy dyes we have designed and synthesized bis-dimethylfluorenyl amine donor groups for DSSC application for the first time to our knowledge. Fig. 1 shows the synthesized photosensitizers for DSSC application. 


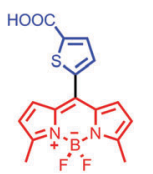

TB5

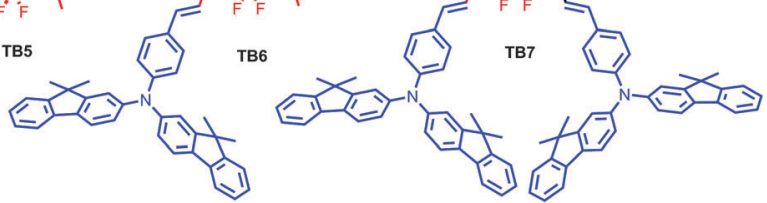

Fig. 1 Synthesized photosensitizers TB5, TB6, and TB7

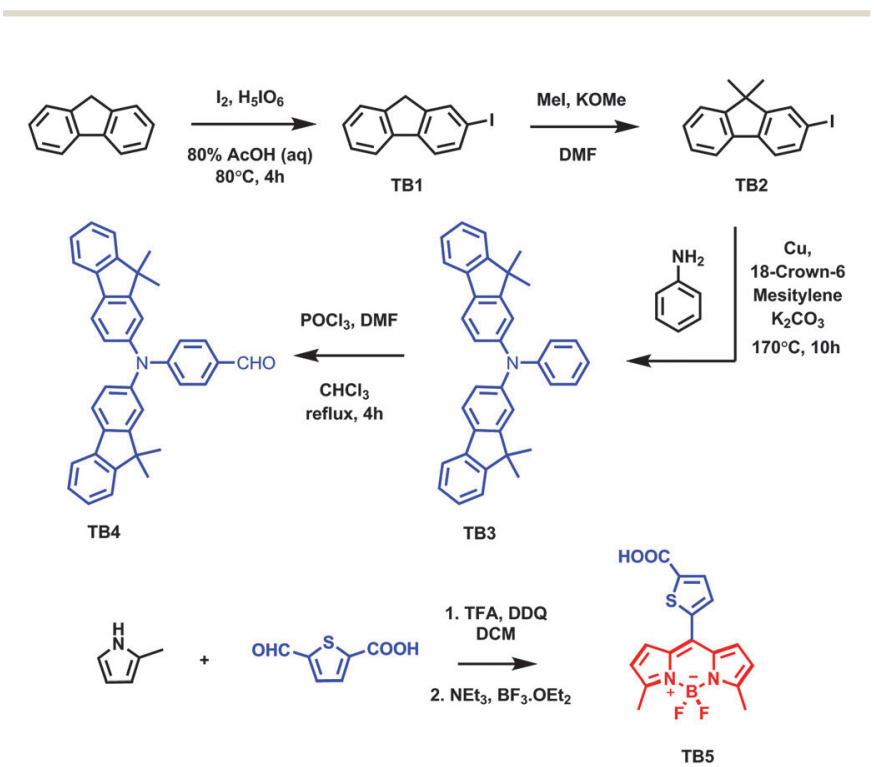

Fig. 2 Synthesis scheme of the precursor molecules.

In the synthesis part (Fig. 2), initially TB1-TB4 have been synthesized. ${ }^{12}$ We first iodinated the fluorene molecule to yield TB1 in 90\% yield. In the second reaction dimethylation reaction was accomplished by using a modified procedure from literature with MeI and KOMe in DMF. Then, in the third step we synthesized $N, N$-bis(9,9-dimethylfluoren-2-yl)aniline under the Ullman reaction conditions by using aniline and coupling reagents at high temperatures. Then, in order to synthesize TB4, which was needed for the Knoevenagel reaction, a typical Vilsmeier formylation reaction in $\mathrm{CHCl}_{3}$ was carried out. After synthesis of the donor part, we moved to the synthesis of the Bodipy dye core. 5-Formyl-2-thiophenecarboxylic acid was obtained from suppliers and reacted with 2-methylpyrrole to get TB5 and upon reaction with the synthesized aldehyde TB4, we obtained both TB6 and TB7 which were tested as photosensitizers in DSSCs (Fig. 3).

\section{Experimental section}

\section{Materials}

All chemicals and solvents obtained from suppliers were used without further purification. Reactions were monitored using thin layer chromatography over Merck TLC Silica gel $60 \mathrm{~F}_{254}$.

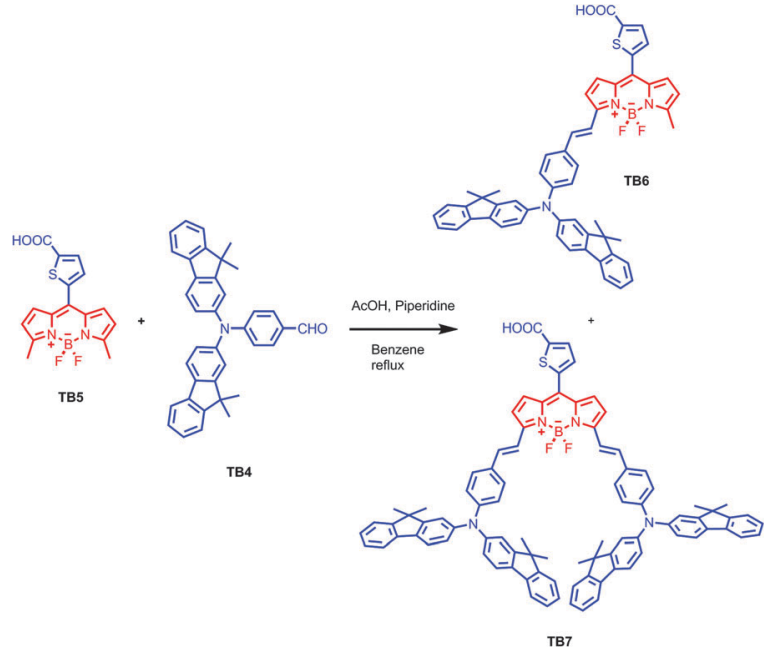

Fig. 3 Synthesis of the final PSs TB6 and TB7.

Chromatography was performed over Merck Silica gel 60 (particle size: 0.040-0.063 mm, 230-400 mesh ASTM).

\section{Characterization}

${ }^{1} \mathrm{H}$ NMR and ${ }^{13} \mathrm{C}$ NMR spectra were recorded at room temperature on Bruker DPX-400 (operating at $400 \mathrm{MHz}$ for ${ }^{1} \mathrm{H}$ NMR and $100 \mathrm{MHz}$ for ${ }^{13} \mathrm{C} \mathrm{NMR}$ ) in MeOD- $d_{4}$ and DMSO- $d_{6}$. Coupling constants ( $J$ values) are given in $\mathrm{Hz}$ and chemical shifts are reported in parts per million (ppm). Splitting patterns are designated as s (singlet), d (doublet), t (triplet), q (quartet), $\mathrm{m}$ (multiplet), and $\mathrm{p}$ (pentet). Absorption spectra were acquired using a Varian Cary-100 spectrophotometer. Mass spectra were recorded on Agilent Technologies 6530 Accurate-Mass Q-TOF LC/MS. Spectrophotometric grade solvents were used for spectroscopy experiments.

\section{Synthetic details}

TB1, TB2, TB3 and TB4 were synthesized according to the literature. $^{12}$

Compound TB5. $400 \mathrm{~mL}$ of argon-degassed $\mathrm{CH}_{2} \mathrm{Cl}_{2}$ was added into 2-methyl pyrrole (11.5 mmol, $0.93 \mathrm{~g}$ ) and 5-formyl2-thiophenecarboxylic acid (5.46 mmol, $0.85 \mathrm{~g}$ ). One drop of TFA was added and the solution was stirred under $\mathrm{N}_{2}$ at room temperature for 1 day. After addition of $p$-chloranil $(5.46 \mathrm{mmol}$, $1.34 \mathrm{~g}$ ) to the reaction mixture, stirring was continued for $30 \mathrm{~min} .5 \mathrm{~mL}$ of $\mathrm{Et}_{3} \mathrm{~N}$ and $5 \mathrm{~mL}$ of $\mathrm{BF}_{3} \cdot \mathrm{OEt}_{2}$ were successively added and after $30 \mathrm{~min}$, the reaction mixture was washed three times with water $(3 \times 100 \mathrm{~mL})$ which was then extracted into the DCM $(3 \times 100 \mathrm{~mL})$ and dried over anhydrous $\mathrm{Na}_{2} \mathrm{SO}_{4}$. The solvent was evaporated and the residue was purified using silica gel column chromatography employing DCM $: \mathrm{MeOH}=$ $80: 20$ as an eluant. Red solid (0.75 g, 40\%). ${ }^{1} \mathrm{H}$ NMR (400 MHz, MeOD- $\left.d_{4}\right): \delta \mathrm{H} 7.79(1 \mathrm{H}, \mathrm{d}, J=3.8 \mathrm{~Hz}, \operatorname{Ar} H), 7.50(1 \mathrm{H}, \mathrm{d}, J=$ $3.9 \mathrm{~Hz}, \operatorname{Ar} H), 7.12(2 \mathrm{H}, \mathrm{d}, J=4.1 \mathrm{~Hz}, \operatorname{Ar} H), 6.44(2 \mathrm{H}, \mathrm{d}, J=4.4 \mathrm{~Hz}$, $\mathrm{Ar} H), 2.62\left(6 \mathrm{H}, \mathrm{s}, \mathrm{CH}_{3}\right)$. MS (TOF-ESI): $\mathrm{m} / \mathrm{z}$ : calcd: 301.0788, found: $301.0798[\mathrm{M}-\mathrm{COOH}]^{-}, \Delta=3.3 \mathrm{ppm} . \varepsilon_{\mathrm{abs}}=43700$ (in $\mathrm{MeOH}$ ). 
Compounds TB6 and TB7. TB5 (0.29 mmol, $0.10 \mathrm{~g})$ and TB4 $(0.38 \mathrm{mmol}, 0.19 \mathrm{~g})$ were added into a $100 \mathrm{~mL}$ round-bottomed flask containing $50 \mathrm{~mL}$ of benzene and to this solution was added piperidine $(0.3 \mathrm{~mL})$ and acetic acid $(0.3 \mathrm{~mL})$. The mixture was heated under reflux by using a Dean Stark trap and the reaction was monitored by TLC (DCM: $\mathrm{MeOH}=80: 20)$. When all the starting material had been consumed, the mixture is concentrated and directly added to a chromatographic column by using DCM : $\mathrm{MeOH} / 80: 20$ and TB7 was separated as a pure product in green color in $52 \%$ yield $(0.152 \mathrm{mmol}, 0.2 \mathrm{~g})$. To separate the mono Knoevenagel product TB6 a second column chromatography was done with DCM:MeOH/90:10 and TB6 was separated as a pure product in $15 \%$ yield in deep blue color (0.04 mmol, $0.035 \mathrm{~g}$ ).

TB6: ${ }^{1} \mathrm{H}$ NMR (400 MHz, DMSO- $\left.d_{6}\right): \delta \mathrm{H} 7.80(2 \mathrm{H}, \mathrm{d}, J=$ $8.0 \mathrm{~Hz}, \mathrm{ArH}), 7.77(2 \mathrm{H}, \mathrm{d}, J=7.3 \mathrm{~Hz}, \mathrm{ArH}), 7.72(1 \mathrm{H}, \mathrm{d}, J=16.3 \mathrm{~Hz}$, $\mathrm{CH}), 7.62(1 \mathrm{H}, \mathrm{d}, J=3.8 \mathrm{~Hz}, \mathrm{ArH}), 7.49-7.60(5 \mathrm{H}, \mathrm{m}, \mathrm{ArH}), 7.43$ $(1 \mathrm{H}, \mathrm{d}, J=16.3 \mathrm{~Hz}, \mathrm{CH}), 7.25-7.38(9 \mathrm{H}, \mathrm{m}, \mathrm{ArH}), 7.05-7.15(4 \mathrm{H}, \mathrm{m}$, $\mathrm{ArH}), 6.48$ (2H, d, ArH), 2.56 (3H, s, $\left.\mathrm{ArCH}_{3}\right), 1.38\left(12 \mathrm{H}, \mathrm{s}, \mathrm{CCH}_{3}\right)$. ${ }^{13} \mathrm{C}$ NMR (100 MHz, DMSO- $d_{6}$ ): $\delta \mathrm{C} 163.6,156.7,155.4,153.8$, 149.4, 146.4, 139.1, 138.6, 135.2, 133.6, 133.0, 131.3, 129.8, 129.4, 127.6, 127.4, 124.4, 123.2, 122.4, 121.7, 120.2, 119.8, 118.5, 116.2, 47.0, 30.1, 27.1 ppm. MS (TOF-ESI): $m / z$ : calcd: 833.3059, found: 833.2955 [M], $\Delta=12.5$ ppm. $\varepsilon_{\text {abs }}=38800$ (in DCM). TB7: ${ }^{1} \mathrm{H}$ NMR (400 MHz, DMSO- $\left.d_{6}\right): \delta \mathrm{H} 7.76(4 \mathrm{H}, \mathrm{d}, J=8.0 \mathrm{~Hz}, \operatorname{ArH}), 7.72(4 \mathrm{H}, \mathrm{d}$, $J=6.8 \mathrm{~Hz}, \mathrm{ArH}), 7.65(2 \mathrm{H}, \mathrm{d}, J=16.6 \mathrm{~Hz}, \mathrm{CH}), 7.40-7.50(12 \mathrm{H}, \mathrm{m}$, ArH; CH), 7.20-7.35 (16H, m, ArH), 7.07 (8H, m, ArH), $1.34(24 \mathrm{H}$, $\left.\mathrm{s}, \mathrm{CCH}_{3}\right) \cdot{ }^{13} \mathrm{C}$ NMR $\left(100 \mathrm{MHz}, \mathrm{DMSO}-d_{6}\right): \delta \mathrm{C} 163.4,155.4,154.8$, 153.7, 149.2, 146.3, 138.5, 137.8, 135.3, 135.2, 132.6, 131.8, 130.0, 129.7, 129.2, 129.0, 127.5, 127.4, 124.3, 123.1, 122.3, 121.7, 120.1, 119.7, 117.9, 116.6, 46.9, 27.1 ppm. MS (TOF-ESI): $\mathrm{m} / \mathrm{z}:$ calcd: 1320.5359, found: 1320.5085 [M], $\Delta=20.7$ ppm. $\varepsilon_{\mathrm{abs}}=53700$ (in DCM).

\section{Electrochemistry of Bodipy dyes}

$\mathrm{CV}$ measurements were made by using $\mathrm{CH}$-Instrument $660 \mathrm{~B}$ Model potentiostat equipment. Solution was prepared in chloroform $\left(10^{-3} \mathrm{M}\right)$. A three-electrode cell was used consisting of a glassy carbon working electrode, a Pt wire counter electrode and an $\mathrm{Ag} / \mathrm{AgCl}$ reference electrode, all placed in a glass vessel. Tetrabutylammonium hexafluorophosphate $\left(\mathrm{TBAPF}_{6}\right), 0.1 \mathrm{M}$, was used as a supporting electrolyte. Ferrocene was used as an internal reference electrode. HOMO/LUMO values were calculated according to literature. ${ }^{6}$

\section{Dye sensitized solar cell device characterization}

The current density versus voltage $(I-V)$ characteristics of the devices were measured using a Keithley 2400 source measurement unit. The device performance was characterized under AM $1.5 \mathrm{G}$ conditions with an illumination intensity of $100 \mathrm{~mW}$ $\mathrm{cm}^{-2}$ using a solar simulator. A special mask was used to define the active area in the devices and measurements were carried out using this special mask. Reproducibility of measurements was checked several times for the accuracy and precision.

\section{Results and discussion}

\section{Optical properties}

After the synthesis of TB6 and TB7 along with the sole Bodipy TB5, we performed photophysical analysis, CV measurements, and theoretical studies in order to determine the suitability of these units for constructing a cell with $\mathrm{TiO}_{2}$ and redox couple $\mathrm{I}^{-} / \mathrm{I}_{3}{ }^{-}$. Absorbance spectra of these dyes in solution (Fig. 4) and on the $\mathrm{TiO}_{2}$ (Fig. S5, ESI $\dagger$ ) surface was investigated and it was found that TB5 exhibited a narrow absorption spectrum with a $\lambda_{\text {max }}$ at $520 \mathrm{~nm}$ in solution, which is characteristic for Bodipy dyes and the molar absorptivity of this compound was 43700 in $\mathrm{MeOH}$ at this wavelength. This compound was barely soluble in DCM or $\mathrm{CHCl}_{3}$. TB6 exhibited a broader absorption spectrum with an absorption maximum at $665 \mathrm{~nm}$ in DCM and fluorene moieties were are also found to absorb strongly in the UV region of the spectrum at around $370 \mathrm{~nm}$. The molar absorptivity of this compound was 38800 at $665 \mathrm{~nm}$. Since the fluorene moieties that inhibit $\pi-\pi$ stacking of the compound increases the solubility; we were able to dissolve them in DCM. TB7 exhibited a strongly red-shifted absorbance maximum at $773 \mathrm{~nm}$ in DCM. This compound was found to be promising in this respect because absorption in the near IR end of the spectrum is highly desired due to strong sunlight illumination in this wavelength region. For example, one of our previously studied sensitizers, PS1, which had a record efficiency among the Bodipy dyes when published in DSSC applications, exhibited an absorption maximum at $724 \mathrm{~nm} .{ }^{13}$ TB7 had a molar absorptivity of 53700 and an absorption maximum at $773 \mathrm{~nm}$. All the three compounds exhibited very weak emission, which was due to the charge transfer events because of the thiophenecarboxylic acid group, which is usual for these types of dyes.

\section{Electrochemical properties}

Cyclic voltammetry results of the synthesized compounds are shown in Fig. 5. The results obtained from these data are summarized in Table 1, showing explicitly the oxidation/ reduction bands of these compounds and the HOMO-LUMO

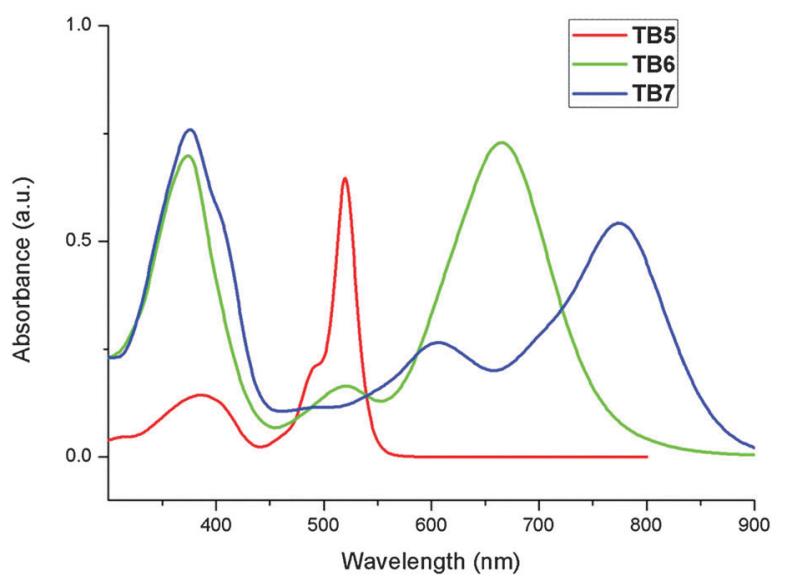

Fig. 4 Absorbance spectra of the compounds synthesized. TB5 in $\mathrm{MeOH}$ and TB6 and TB7 in DCM. 


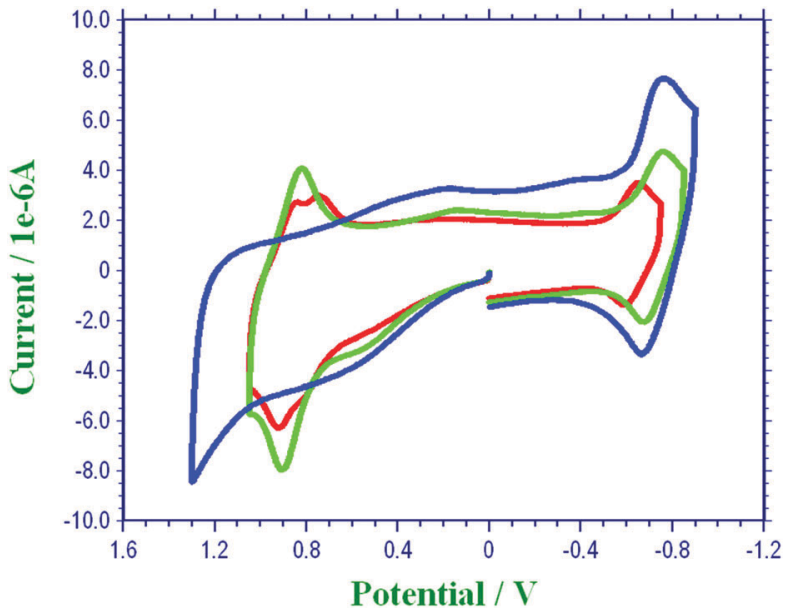

Fig. 5 Cyclic voltammetry measurements of TB5 (blue), TB6 (green) and TB7 (red)

Table 1 Redox potentials and $E_{\text {HOMO }}$ and $E_{\text {LUMO }}$ levels of Bodipy derivatives

\begin{tabular}{lllllll}
\hline & $\begin{array}{l}E_{\text {Ox }}{ }^{a} \\
(\text { Volt })\end{array}$ & $\begin{array}{l}E_{\text {red }}{ }^{b} \\
\text { (Volt) }\end{array}$ & $\begin{array}{l}E_{\text {fer }}{ }^{c} \\
(\text { Volt })\end{array}$ & $\begin{array}{l}E_{\text {HOMO }}{ }^{d} \\
(\mathrm{eV})\end{array}$ & $\begin{array}{l}E_{\text {LUMO }}{ }^{e} \\
(\mathrm{eV})\end{array}$ & $E_{\text {Band gap }}{ }^{f}$ \\
\hline TB5 & 0.54 & -0.70 & 0.58 & 4.84 & 3.52 & 1.32 \\
TB6 & 0.87 & -0.72 & 0.57 & 5.10 & 3.51 & 1.59 \\
TB7 & 0.83 & -0.63 & 0.61 & 5.02 & 3.56 & 1.46
\end{tabular}

${ }^{a}$ Oxidation potential of Bodipy derivatives. ${ }^{b}$ Reduction potential of Bodipy derivatives. ${ }^{c}$ Potential of ferrocene, the internal reference electrode. ${ }^{d}$ HOMO energy level of Bodipy derivatives. ${ }^{e}$ LUMO energy level of Bodipy derivatives. ${ }^{f}$ Energy band gap of Bodipy derivatives.

band levels and band gaps. Energy levels of the HOMO and the LUMO are highly important in the DSSC concept. To summarize, upon photoexcitation of the dye molecules, electrons are excited from the HOMO to the LUMO of the dye and then electron injection from the LUMO to the conduction band of $\mathrm{TiO}_{2}$ takes place. Hence, the LUMO energy level should be higher in energy than that of the conduction band of $\mathrm{TiO}_{2}$.

The energy level of the conduction band was estimated to be $4.2 \mathrm{eV}^{2 a}$ In all three Bodipy dyes; TB5, TB6, and TB7, their LUMO levels were convenient for electron injection with 3.51$3.56 \mathrm{eV}$ values which were higher in energy, as shown in Fig. 6 . HOMO levels of the Bodipy dyes should also be considered since their energy level should be lower than the redox couple energy level $\left(\mathrm{I}^{-} / \mathrm{I}_{3}{ }^{-}\right)$, which was also calculated to be $4.9 \mathrm{eV}$. In Table 1, we can observe that only TB5 was not convenient for reducing the Bodipy dye by the redox couple. On the other hand, TB6 and TB7 had the desired energy levels of 5.10 and $5.02 \mathrm{eV}$, respectively. However, it was emphasized in a recent review by Ooyama and Harima that, the energy difference between these levels should be at least $0.2-0.3 \mathrm{eV}$ for an efficient electron regeneration. ${ }^{13}$ In our molecules, these were 0.2 and $0.12 \mathrm{eV}$ for TB6 and TB7, respectively. Although, these values seem to be appropriate, a larger gap would be better suited.

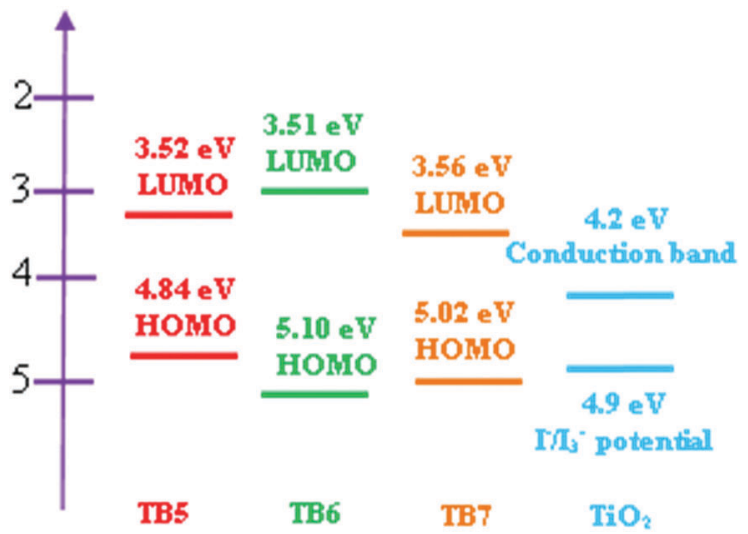

Fig. 6 Energy level diagrams of TB5, TB6 and TB7 from the electrochemical data summarized in Table 1.

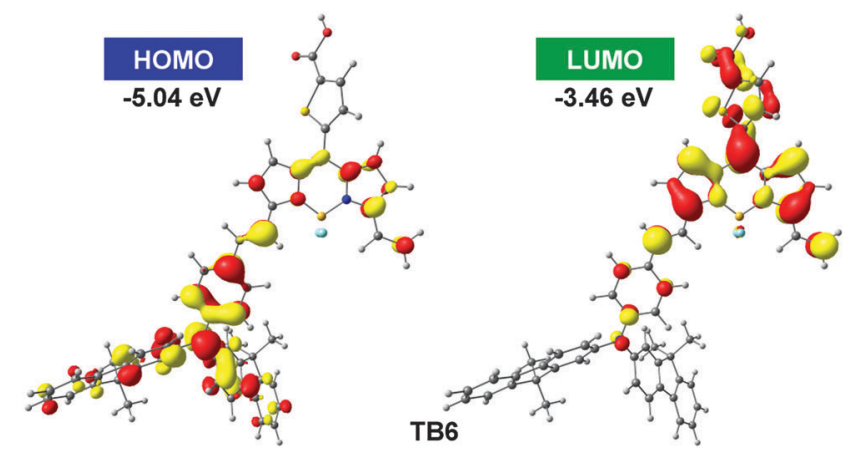

Fig. 7 Schematic representation of HOMOs and LUMOs of TB6. The UB3LYP/CEP-31G level of theory.

\section{Theoretical studies}

In order to understand the structure-performance relationship of the photosensitizers, we calculated the HOMO-LUMO diagrams (for calculation details, see the ESI $\dagger$ ). The HOMOLUMO of TB6 are shown in Fig. 7, in which the HOMO molecular orbital electron density can be seen on the bisdimethylfluorenyl group and the LUMO electron density on the Bodipy and the thiophene unit. It was apparent that upon photoexcitation, electrons moved from the bis-dimethylfluorenyl unit to the anchoring thiophene unit with $\pi-\pi^{*}$ type excitation. However, in the LUMO $\pi$-electron localization on the Bodipy core was not desired and this may be responsible for the low electron injection efficiency. In optimized geometry of the molecule, the angle between the Bodipy plane and the thiophene carboxylic acid unit plane was $46.6^{\circ}$, which seemed to be enough to achieve an effective conjugation between these two units. Although this angle seemed to be large, it was smaller when compared to that of the 8-aryl Bodipy molecules (almost $90^{\circ}$ ) synthesized from 2,4-dimethylpyrrole due to the steric effect of the extra methyl units and in this case, the $\pi$-electron conjugation was limited.

The electron localization of the HOMO-LUMO of TB7 (Fig. 8) was similar to that of TB6 according to the computational studies. The HOMO was localized mainly on the donor group, 


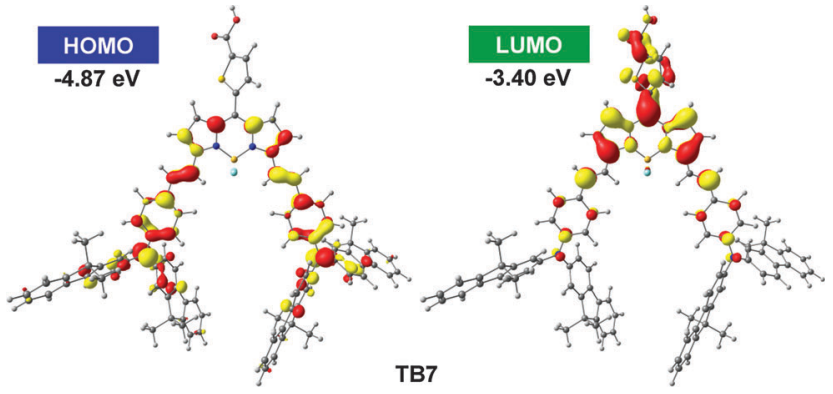

Fig. 8 Schematic representation of HOMOs and LUMOs of TB7. The UB3LYP/CEP-31G level of theory.

Table 2 TD-DFT transitions for TB6 and TB7

\begin{tabular}{llll} 
Dye $\mathrm{S}_{0} \rightarrow \mathrm{S}_{1}$ Transition Absorption $(\mathrm{nm})$ & Oscillator strength & LHE $(\%)$ \\
\hline TB6 HOMO $\rightarrow$ LUMO & 869 & 0.9619 & 89 \\
TB7 HOMO $\rightarrow$ LUMO & 975 & 0.6896 & 79
\end{tabular}

while the LUMO on thiophene and Bodipy. The angle between the Bodipy plane and thiophene $\left(49.1^{\circ}\right)$ was slightly wider compared to that of TB6.

The light-harvesting efficiency (LHE) ${ }^{14}$ of the dyes were calculated using LHE $=1-10^{-f}$, where $f$ is the oscillator strength of the dyes. LHE values were $89 \%$ and $79 \%$ for TB6 and TB7, respectively. TD-DFT results are summarized in Table 2. Besides an acceptable deviation of the computed absolute numerical values from the measurements, the TD-DFT results are in very good agreement with the prediction of the red shifting (106 nm computed) of the main $\mathrm{S}_{0} \rightarrow \mathrm{S}_{1}$ transition and the LHE trend (in favor of TB6).

\section{Photovoltaic performances}

After careful investigation of CV results, we constructed the cells by using typical methods as mentioned in the experimental section. Firstly, we measured the short-circuit photocurrent density $\left(J_{\mathrm{sc}}\right)$, the open-circuit photovoltage $\left(V_{\mathrm{oc}}\right)$, the photocurrent-voltage curve ( $J-V$ curve) (Fig. 9), the fill factor (ff)

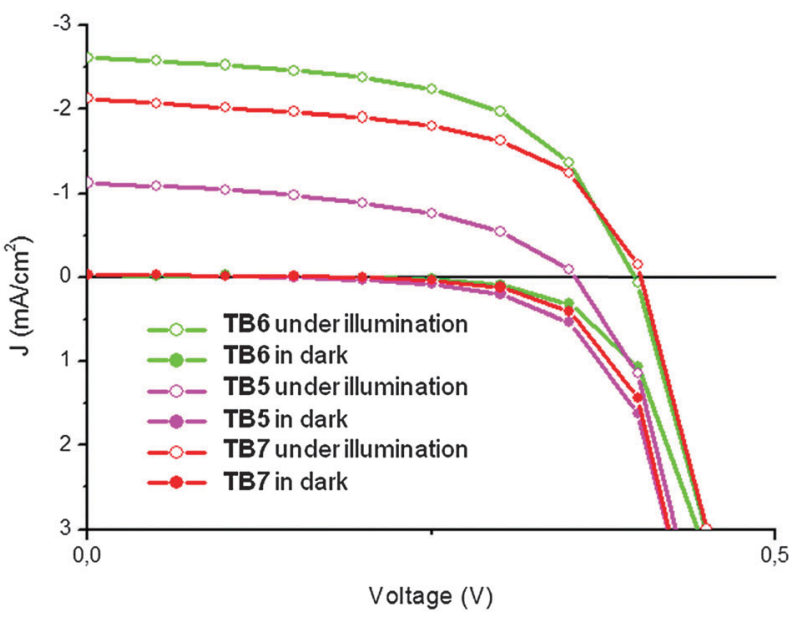

Fig. 9 Current vs. voltage graphs of the photosensitizers.
Table 3 Photovoltaic performance of $\mathrm{TiO}_{2}$-based dye-sensitized solar cells

\begin{tabular}{lllll}
\hline \multicolumn{2}{c}{$J_{\text {sc }}\left(\mathrm{mA} \mathrm{cm}^{-2}\right)$} & $V_{\text {oc }}(\mathrm{mV})$ & ff & \multicolumn{2}{l}{$\eta(\%)$} & Adsorbed dye $\left(\times 10^{-7} \mathrm{~mol} \mathrm{~cm}^{-2}\right)$ \\
\hline TB5 1.12 & 370 & 0.48 & 0.19 & 1.7 \\
TB6 2.61 & 400 & 0.57 & 0.59 & 3.9 \\
TB7 2.12 & 400 & 0.58 & 0.49 & 3.0
\end{tabular}

and the incident photon-to-current conversion efficiency (IPCE) (Fig. S6, ESI $\dagger$ ) and by the help of these parameters, we calculated the solar energy-to-electricity conversion yield $(\eta)$. These values are tabulated in Table 3. TB6 produced more photocurrent with $2.61 \mathrm{~mA} \mathrm{~cm}{ }^{-2}$ under AM 1.5 simulated sunlight $\left(100 \mathrm{~mW} \mathrm{~cm}^{-2}\right)$. The cell constructed from TB6 had an opencircuit voltage of $400 \mathrm{mV}$ and a fill factor of 0.57 and the calculated total sunlight-to-electricity conversion yield $(\eta)$ was 0.59 (Table 3). This made this dye more efficient compared to TB5 and TB7 without using chenodeoxycholic acid as a coadsorbent. Herein, it is worth noting that the adsorbed amount of TB6 on the $\mathrm{TiO}_{2}$ surface was more (see Table 3) so this may also be a reason for this result. Also, the incident photon-to-current conversion efficiency (IPCE) spectrum gave us information about the response of the dye molecules upon illumination with the monochromatic light over a wide range of wavelengths. This spectrum resembles the absorbance of the dyes, interestingly large amounts of photocurrent were observed for TB6 and TB7 in the range 300-400 $\mathrm{nm}$ (Fig. S5 and S11, ESI $\dagger$ ). However, the irradiation of sunlight in this range is not strong and its reflection to the solar-light photocurrent is limited. For TB6 we observed effective photocurrent in the range $600-700 \mathrm{~nm}$.

We also constructed the cell from TB5 for comparison and we reached lower solar cell parameter values using this dye with $\eta=0.19$. For $\mathbf{T B} 7$, we acquired similar but also lower values compared to TB6. The critical parameters for this dye exhibited a highly panchromatic nature of the IPCE spectrum (Fig. S5, ESI $\dagger$ ). Although the photocurrent was low, it was generated in a wide spectrum, ranging $500-850 \mathrm{~nm}$. The open-circuit voltage $\left(V_{\text {oc }}\right)$ was $400 \mathrm{mV}$, the photocurrent density was $2.12 \mathrm{~mA} \mathrm{~cm}^{-2}$

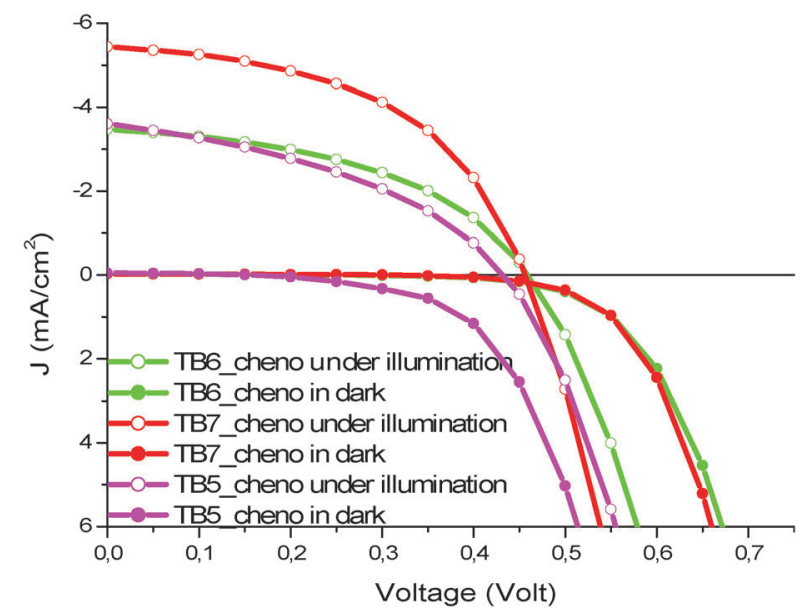

Fig. 10 Current vs. voltage graphs of the photosensitizers after adding Cheno (2 mM). 
Table 4 Photovoltaic performance of $\mathrm{TiO}_{2}$-based dye-sensitized solar cells after adding Cheno (2 $\mathrm{mM})$

\begin{tabular}{lllll}
\hline & $J_{\text {sc }}\left(\mathrm{mA} \mathrm{cm}^{-2}\right)$ & $V_{\text {oc }}(\mathrm{mV})$ & ff & $\eta(\%)$ \\
\hline TB5 & 3.60 & 450 & 0.38 & 0.61 \\
TB6 & 3.47 & 450 & 0.47 & 0.73 \\
TB7 & 5.32 & 450 & 0.52 & 1.25
\end{tabular}

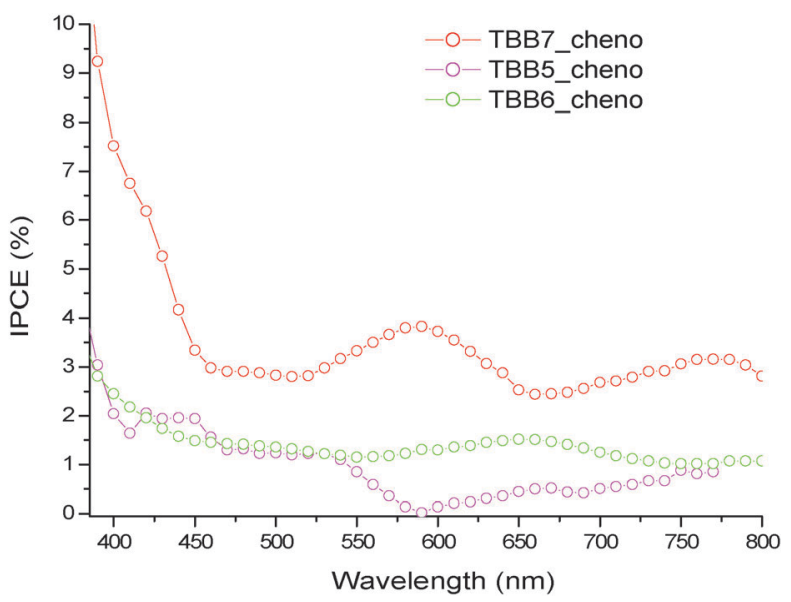

Fig. 11 Incident photon-to-current conversion efficiencies of the liquid electrolyte based-DSSCs as a function of wavelength after adding Cheno.

and the fill factor was 0.58. The overall sunlight energy-toelectricity conversion yield $(\eta)$ was 0.49 .

After these initial results, we constructed the DSSCs again but this time we used the coadsorbent chenodeoxycholic acid $(2 \mathrm{mM})$ in order to inhibit the stacking of the dye molecules on the $\mathrm{TiO}_{2}$ surface. The IPCE spectrum and the $J-V$ curve are shown in Fig. 11 and 10, respectively. Table 4 shows the photovoltaic performances and this time we can observe an increase in the efficiency of all the photosensitizers. The major increase in the overall efficiency was observed in TB7 from 0.49 to 1.25 . The $J_{\mathrm{sc}}$ of this cell increased from 2.12 to $5.32 \mathrm{~mA} \mathrm{~cm}^{-2}$. We observed a small increase with TB6 in overall efficiency from 0.59 to 0.73 . These results confirm that $\mathbf{T B} 7$ was superior to $\mathbf{T B 6}$ when a coadsorbent molecule was used.

\section{Conclusion}

The novelties of this study include a bulky donor group and a thiophene $\pi$-electron linker. As a donor group, we used the bisdimethylfluorenyl amine group which was used for the first time with Bodipy dyes as far as we know and due to its sterically bulky structure it is expected to inhibit the aggregation of the dyes on the $\mathrm{TiO}_{2}$ nanocrystalline surface. After constructing the cells using the Bodipy dyes that we have synthesized, the overall efficiency $(\eta)$ was calculated to be 0.59 for TB6 and 0.49 for TB7. By using chenodeoxycholic acid as a coadsorbent, we observed an increase in efficiency of all the photosensitizers tested. And the efficiency of TB7 was observed to increase from 0.49 to 1.25. Although we used the bulky donor group, it seemed that using a coadsorbent was still needed to inhibit the stacking of the dye molecules on $\mathrm{TiO}_{2}$. The second parameter we used in these molecules was the $\pi$-electron linker unit, thiophene. This group has been widely used in various dye-sensitized solar cells due to its high $\pi$-electron localization ability and when we inspected the LUMOs we observed that the electron density moved successfully from the donor group to the acceptor unit. The main obstacle may be the fact that the electron density was not fully transferred to the acceptor and there was some residual density on the Bodipy core. This complication may be resolved by using the oligothiophene unit as a $\pi$-electron linker for a more efficient electron transfer. Further studies to solve the addressed problems and develop more efficient DSSCs suitable for near-IR sensitization are underway.

\section{Acknowledgements}

We acknowledge Prof. Engin U. Akkaya for fruitful discussions, and Tuğba Özdemir Kütük for help in synthesis. We acknowledge the Alexander von Humboldt Foundation (AvH), the Turkish Scientific and Technological Research Council (TUBITAK), Grant No. 114F161, the UNESCO-LOREAL Foundation and the Turkish Academy of Sciences (TUBA).

\section{Notes and references}

1 (a) B. O'Regan and M. Grätzel, Nature, 1991, 353, 737; (b) M. K. Nazeeruddin, A. Kay, I. Rodicio, R. HumphryBaker, E. Muller, P. Liska, N. Vlachopoulos and M. Grätzel, J. Am. Chem. Soc., 1993, 115, 6382; (c) A. Hagfeldt and M. Gratzel, Acc. Chem. Res., 2000, 33, 269; (d) M. Grätzel, Nature, 2001, 414, 338; (e) M. K. Nazeeruddin, Coord. Chem. Rev., 2004, 248, 1161; $(f)$ M. K. Nazeeruddin, F. De Angelis, S. Fantacci, A. Selloni, G. Viscardi, P. Liska, S. Ito, T. Bessho and M. Grätzel, J. Am. Chem. Soc., 2005, 127, 16835; $(g)$ A. Jager-Waldau, Renewable Sustainable Energy Rev., 2007, 11, 1414; (h) H. S. Jung and J.-K. Lee, J. Phys. Chem. Lett., 2013, 4, 1682.

2 (a) S. Wenger, P. A. Bouit, Q. Chen, J. Teuscher, D. Di Censo, R. Humphry-Baker, J. E. Moser, J. L. Delgado, N. Martín, S. M. Zakeeruddin and M. Grätzel, J. Am. Chem. Soc., 2010, 132, 5164; (b) Y. Ooyama and Y. Harima, Eur. J. Org. Chem., 2009, 2903; (c) A. Mishra, M. K. R. Fischer and P. Bäuerle, Angew. Chem., Int. Ed., 2009, 48, 2474; (d) J. N. Clifford, E. Martinez-Ferrero, A. Viterisi and E. Palomares, Chem. Soc. Rev., 2011, 40, 1635; (e) S. Erten-Ela and K. Ocakoglu, J. Ind. Eng. Chem., 2014, 20, 474.

3 (a) A. Loudet and K. Burgess, Chem. Rev., 2007, 107, 4891; (b) R. Ziessel, G. Ulrich and A. Harriman, New J. Chem., 2007, 31, 496; (c) G. Ulrich, R. Ziessel and A. Harriman, Angew. Chem., Int. Ed., 2008, 47, 1184; (d) M. Buyuktemiz, S. Duman and Y. Dede, J. Phys. Chem. A, 2013, 117, 1665.

4 S. Hattori, K. Ohkubo, Y. Urano, H. Sunahara, T. Nagano, Y. Wada, N. V. Tkachenko, H. Lemmetyinen and S. Fukuzumi, J. Phys. Chem. B, 2005, 109, 15368. 
5 (a) S. Erten-Ela, D. Yilmaz, B. Icli, Y. Dede, S. Icli and E. U. Akkaya, Org. Lett., 2008, 10, 3299; (b) D. Kumaresan, R. P. Thummel, T. Bura, G. Ulrich and R. Ziessel, Chem. Eur. J., 2009, 15, 6335; (c) T. Rousseau, A. Cravino, T. Bura, G. Ulrich, R. Ziessel and J. Roncali, Chem. Commun., 2009, 1673; (d) T. Rousseau, A. Cravino, T. Bura, G. Ulrich and R. Ziessel, J. Mater. Chem., 2009, 19, 2298; (e) C. Y. Lee and J. T. Hupp, Langmuir, 2010, 26, 3760; $(f)$ B. Kim, B. Ma, V. R. Donuru, H. Liu and J. M. J. Frèchet, Chem. Commun., 2010, 46, 4148; $(g)$ T. Rousseau, A. Cravino, E. Ripaud, P. Leriche, S. Rihn, A. D. Nicola, R. Ziessel and J. Roncali, Chem. Commun., 2010, 46, 5082; (h) S. Kolemen, Y. Cakmak, S. Erten-Ela, Y. Altay, J. Brendel, M. Thelakkat and E. U. Akkaya, Org. Lett., 2010, 12, 3812; (i) T. Bura, N. Leclerc, S. Fall, P. Lévêque, T. Heiser, P. Retailleau, S. Rihn, A. Mirloup and R. Ziessel, J. Am. Chem. Soc., 2012, 134, 17404; $(j)$ S. Kolemen, Y. Cakmak, T. Ozdemir, S. Erten-Ela, M. Buyuktemiz, Y. Dede and E. U. Akkaya, Tetrahedron, 2014, 70, 6229; ( $k$ ) Y. Ooyama, Y. Hagiwara, T. Mizumo, Y. Harima and J. Ohshita, RSC Adv., 2013, 3, 18099; (l) Y. Ooyama, Y. Hagiwara, T. Mizumo, Y. Harima and J. Ohshita, New J. Chem., 2013, 37, 2479.

6 (a) S. Kolemen, O. A. Bozdemir, Y. Cakmak, G. Barin, S. ErtenEla, M. Marzalek, J.-H. Yum, S. M. Zakeeruddin, M. K. Nazeeruddin, M. Grätzel and E. U. Akkaya, Chem. Sci., 2011, 2, 949; (b) S. Erten-Ela and A. C. Cakir, Energy Sources, Part A, 2015, 37, 807; (c) S. Erten-Ela and K. Ocakoglu, J. Ind. Eng. Chem., 2014, 20, 474.
7 (a) M. Mao, X.-L. Zhang, X.-Q. Fang, G.-H. Wu, Y. Ding, X.-L. Liu, S.-Y. Dai and Q.-H. Song, Org. Electron., 2014, 15, 2079; (b) M. Mao, X.-L. Zhang, X.-Q. Fang, G.-H. Wu, S.-Y. Dai, Q.-H. Song and X.-X. Zhang, J. Power Sources, 2014, 268, 965; (c) M. Grätzel, J. Photochem. Photobiol., C, 2003, 4, 145.

8 (a) Y. Kubo, D. Eguchi, A. Matsumoto, R. Nishiyabu, H. Yakushiji, K. Shigakib and M. Kaneko, J. Mater. Chem. A, 2014, 2, 5204; (b) O. Buyukcakir, O. A. Bozdemir, S. Kolemen, S. Erbas and E. U. Akkaya, Org. Lett., 2009, 11, 4644; (c) Y. Cakmak, S. Kolemen, S. Duman, Y. Dede, Y. Dolen, B. Kilic, Z. Kostereli, L. T. Yildirim, A. L. Dogan, D. Guc and E. U. Akkaya, Angew. Chem., Int. Ed., 2011, 50, 11937.

9 Z. Dost, S. Atilgan and E. U. Akkaya, Tetrahedron, 2006, 62, 8484.

10 Y. Liu, N. Xiang, X. Feng, P. Shen, W. Zhou, C. Weng, B. Zhao and S. Tan, Chem. Commun., 2009, 2499.

11 (a) H. Choi, J. K. Lee, K. Song, S. O. Kang and J. Ko, Tetrahedron, 2007, 63, 3115; (b) M. S. Kang, S. H. Kang, S. G. Kim, I. T. Choi, J. H. Ryu, M. J. Ju, D. Cho, J. Y. Lee and H. K. Kim, Chem. Commun., 2012, 48, 9349; (c) J. Kim, H. M. Ko, N. Cho, S. Paek, J. K. Lee and J. Ko, RSC Adv., 2012, 2, 2692.

12 (a) H. Doi, M. Kinoshita, K. Okumoto and Y. Shirota, Chem. Mater., 2003, 15(5), 1080; (b) F. Yang, X. L. Xu, Y. H. Gong, W. W. Qiu, Z. R. Sun, J. W. Zhou, P. Audebert and J. Tang, Tetrahedron, 2007, 63(37), 9188.

13 Y. Ooyama and Y. Harima, ChemPhysChem, 2012, 13, 4032. 14 D. Vijay, E. Varathan and V. Subramanian, J. Mater. Chem. A, 2013, 1, 4358. 